\title{
The Role of Anatomy Education in Facilitating Multidisciplinary Collaboration in the Treatment of Musculoskeletal Conditions - an Example from Australia
}

\author{
El Papel de la Educación de la Anatomía en la Facilitación de la Colaboración Multidisciplinaria \\ en el Tratamiento de las Afecciones Musculoesqueléticas - un Ejemplo de Australia
}

\author{
Rosemary Giuriato*,**; Nalini Pather*; Ken Ashwell* \& Goran Strkalj ${ }^{* *}$
}

GIURIATO, R.; PATHER, N.; ASHWELL, K. \& STRKALJ, G. The role of anatomy education in facilitating multidisciplinary collaboration in the treatment of musculoskeletal conditions - an example from Australia. Int. J. Morphol., 34(4):1424-1428, 2016.

SUMMARY: Emerging changes to the healthcare system are promoting the adoption of an integrative medicine and a more patient-centred approach to healthcare. A multidisciplinary approach to the management of musculoskeletal conditions has a potential to ease the pressure off the emergency public health care system. Interprofessional collaboration in health care is paramount for this synergism to occur. It is crucial that treatment options be consistent and transparent across different health professions in order for optimum patient centred care. Using the Australian educational and health setting as an example, it is argued in this paper that anatomy education could play an important role in facilitating this consistency and transparency. The first decisive step in this process would be to review the alignment of anatomy syllabi across the academic programs of different health professions. The review and comparison of anatomy content taught across the different health professional curricula should expedite the acceptance of one profession by another. This alignment of anatomy teaching would aid interprofessional relations and ultimately collaboration, beginning from education of students through to professional practice and encompassing accreditation guidelines.

KEY WORDS: Anatomy education; Musculoskeletal conditions; Interprofessional collaboration; Multidisciplinary health care

\section{INTRODUCTION}

The 2012 Global Burden of Disease Study reported that musculoskeletal conditions such as arthritis and back pain affected more than 1.7 billion people worldwide, are the second greatest cause of disability and have the fourth greatest impact on the overall health of the world's population (Murray et al., 2013). With the increasing trend towards an ageing population, there is a proportionate rise in the noncommunicable diseases (NCDs) related to degeneration of the musculoskeletal system (Hoy et al., 2014a).

The resultant requirement for appropriate treatment modalities for these ageing patients increases the burden on medical and allied health resources (Hoy et al., 2014b) and more directly on patient finances. There is growing consensus among health professionals that the optimal care for musculoskeletal disorders is best achieved by a multidisciplinary health care team approach (Thistlethwaite et al., 2014). It is therefore important that information and treatment options be consistent and transparent across health professionals and that they closely collaborate with each other (O'Sullivan, 2012) to provide the patient with the best clinical outcome.

In western countries, patients are empowered by their knowledge and ability to autonomously decide their preferred approach to management of chronic musculoskeletal conditions. They are a driving force in enforcing collaboration between their medical practitioners and allied health professionals often as a result of their dissatisfaction at the perceived inability of the medical system to address their chronic disease and to effectively coordinate a collaborative approach to their healthcare (Delgado et al., 2014). This need for a multidisciplinary approach has indirectly contributed to the rising consumer interest in allied and complementary medicine especially with respect to the management of musculoskeletal conditions (Coulter \&

\footnotetext{
* School of Medical Sciences, The University of New South Wales, Sydney, Australia,

** Department of Chiropractic, Macquarie University, Sydney, Australia.
} 
Willis, 2004). In Australia, the allied health workforce has the ability to ease the pressure off the emergency public healthcare system, whilst maintaining patient-centred care. Interprofessional collaboration in healthcare is considered crucial for the delivery of high quality patient care (Harris et al., 2016). Along with mastering specific discipline-based requirements, health professionals must understand each other's specialised roles and communicate effectively within the healthcare team. Interprofessional teamwork in healthcare has been said to foster better utilisation of human resources, enhance workflow, promote economic sustainability and increase patient satisfaction (Frenk et al., 2011, McKinlay \& Pullon, 2014).

\section{INTERPROFESSIONAL TEAMWORK AND EDUCATION}

One area of health in which multidisciplinary care is important is in the management of musculoskeletal conditions. These patient management teams often include health professionals such as doctors, physiotherapists, chiropractors, osteopaths and exercise physiologists amongst others. For these teams to work optimally, the health professionals need to have an understanding and appreciation of each other's discipline. It can be argued that this understanding and appreciation should begin much earlier that clinical practice and should involve collaboration during professional training and a similarly aligned standards base in the medical sciences.

Ideally, students of the various health professions should commence interprofessional collaboration during the period of their professional education. The experiences of dealing with students from other healthcare professions enhances students' ability to communicate with each other across disciplines and recognise the specialised skills of other health care workers whilst working toward common goals related to patient care (McBride \& Drake, 2015).

It is seen that students from different health professions identify with their chosen profession at an early stage of their academic programs (Thistlethwaite, 2015). Brosnan (2015) highlights that a university degree qualification in a specific allied health discipline is not necessarily a marker of acceptance or "legitimacy of a profession" by another and that what is required is a review and transparency of the content of degrees (Brosnan). Despite this need and common purpose, the training of each health professional has largely occurred independently with limited cross-communication. Familiarity with curricular of other professional programs, would increase the appreciation and intricacies and complexities of alternative approaches to patient care and would also assist to remove personal biases which often exist due to lack of knowledge or information (Ho et al., 2008; Pecukonis et al., 2008).

\section{ANATOMY: THE UNION OF CURRENCY BETWEEN DISCIPLINES}

One way to achieving this transparency would be a better understanding and knowledge of the anatomy content in each of the varied allied health education programs. This knowledge would assist in greater interprofessional understanding resulting in better collaboration between the various disciplines and would align with the current transparency of anatomy content in medical programs. It would also go a long way in assisting in the reduction of perceived differences in professional roles and hopefully result in cooperative health professional approaches for the benefit of the patient.

This paper purports that a logical starting point for this transformation is a review and comparison of the anatomy content and teaching approaches of the allied health professional programs. Anatomy is a fundamental medical science in all healthcare professions and is generally introduced in the initial years of all health professional education. It is particularly relevant and important in disciplines focusing on the management of musculoskeletal disorders (Yammine, 2014) and applicable as a prerequisite unit to the understanding and application of applied sciences such as biomechanics and the study of orthopaedics which assists in formulating plausible differential diagnoses for a number of given clinical scenarios (Elizondo-Omaña \& Lopez, 2008).

Gross anatomy has been identified as a suitable core unit of study to compare and contrast among all health professional education programs because it is recognised for its role in developing and embedding graduate capabilities and attitudes related to content knowledge, professionalism, effective communication skills and team-work (Moxham et al., 2014; Chan \& Pawlina, 2015). Anatomy can be described as offering students "authentic learning" experiences (Lombardi, 2007) in preparing them for the real world where they will be faced with the need to make complex clinical decisions. Authentic early experiential learning is used to describe the type of learning that occurs when students are exposed to early clinical exposure to the health care environment in their program of study (Pawlina \& Drake, 2016). It is this "authentic early learning" framework which exists in anatomy programs across all allied health education programs, which could offer students across disciplines the opportunity to collaborate on learning objectives in common (Barrow, 2012). 
Over the past few decades, numerous investigations and reviews have been undertaken of anatomy teaching in medical programs with respect to content, varied teaching modalities, sequence of delivery, integration of content and value to the clinician (Turney, 2007). These findings have shown not only a need for uniformly accepted standards and benchmarking across medical programs but also the apparent paucity of information on the anatomy curriculum in allied health education programs. This is potentially a major factor that impedes the efficacy of multidisciplinary healthcare teams and future integrated care. This knowledge would be a useful standard against which Australian allied health education programs could be measured and compared.

\section{ACCREDITATION}

Notwithstanding the collaborative team approach addressing the chronic and complex long term musculoskeletal conditions of an ageing population, the bulk of health professional education in universities and clinical environments is conducted uniprofessionally or, as the global literature describes this phenomenon, 'in silos' (Bainbridge, 2014). Training and educating health care practitioners in isolation from other health care practitioners, results in limited knowledge of interprofessional cultural competence levels (Pecukonis et al.).

Health professional education in Australia, is no longer considered fit for purpose in terms of educating students to be work ready to collaborate and provide team-based care. Recommendations for a nationally coordinated approach to building interprofessional curriculum in addition to the goal of incorporating interprofessional practice standards and interprofessional learning outcomes into the accreditation standards of all Australian health professions (Steketee et al.) have been made. In order for this to take place, the current paucity of information and the lack of knowledge of specific requirements of anatomy content in accreditation requirements in allied health programs' accreditation standards and guidelines documents needs to be addressed. Given the role of accreditation to verify the credibility, integrity and quality of academic programs, a transparent analysis of anatomy content in these professional programs would assist each health discipline to appreciate the respective approaches to patient care and it would assist to remove personal biases often due to lack of information (Ho et al.; Pecukonis et al.).

The knowledge and skills required by health professionals, changes over time. These changes are driven by emerging new scientific advances and in some cases professional activities that were once undertaken by one discipline, become the scope of another profession (Ho et al.). While the roles and responsibilities of each health profession are defined separately, accreditation must stay current and abreast of the changes across the health care disciplines and be reflected in up to date standards and guidelines in order to ascertain and confirm effective, comparable maintenance of standards across professions. There is urgency for the requirement of this evidence framework in order to support future policy decision making regarding equitable accreditation standards across the various healthcare professions in anatomy content.

Review of publicly available documents of accrediting bodies of healthcare professionals in Australia, does not currently provide detailed guidelines for program anatomy content in the accreditation standards and guidelines against which academic programs are benchmarked. The lack of national guidelines in programs for anatomy instruction results in a great range of variability in anatomy taught in these programs and presents a problem for institutions deciding what represents adequate anatomy knowledge (Farey et al., 2014).

\section{CONCLUSION}

There is consensus that interprofessional collaboration is crucial for the delivery of high quality patient care (Frenk et al.). Allied health professions have developed specialised advanced and extended scope roles over the past decade for the benefit of patient outcomes, allied health professionals' satisfaction and to meet labour and workforce demands (Skinner et al., 2015). For professionals to work effectively in an interprofessional relationship there needs to be evidence of acceptable education standards and the need for a standardisation of minimum competency requirements across the different health disciplines' programs of study. The comparison of anatomy content and standards across programs could assist in providing information in order to establish guidelines and recommendations to assist in refining and improving academic programs. There is a need to identify anatomy education in undergraduate or preprofessional academic programs across the varied health care disciplines that treat chronic musculoskeletal conditions. This review needs to focus on curriculum, student learning outcomes, assessments, program resources, content integration and faculty qualifications for the purposes of establishing policy in the accreditation of anatomy in these programs. This information will be essential in order to enable comparison of anatomy programs and to investigate alignment of anatomy curricula across different health disciplines that all consider anatomy to be the 'basic language' that binds them together (Di Dio, 1999). The establishment of parallel benchmarking will enhance and further strengthen 
respect and collaboration between health disciplines for the common goal of a better patient focused health care.

Education faculties must establish the respect required for students from different disciplines to develop respect for other professional disciplines. Showing similarity in basic foundation anatomy education curricula in addition to confirmation of similar goals, values and beliefs would be imperative to attain this outcome.
The review of trends, issues and standards in anatomy education across varied health discipline programs would be a great framework for providing the information that is currently lacking and would assist in breaking down the barriers that often exist or are perceived between professions. The resultant potential collaboration of disciplines, in light of an ageing population and a rising incidence of chronic and long term health conditions would benefit the delivery of health care.

GIURIATO, R.; PATHER, N.; ASHWELL, K. \& STRKALJ, G. El papel de la educación de la anatomía en la facilitación de la colaboración multidisciplinaria en el tratamiento de las afecciones musculoesqueléticas - un ejemplo de Australia. Int. J. Morphol., 34(4):1424-1428, 2016.

RESUMEN: Los cambios emergentes en el sistema de salud están promoviendo la adopción de una medicina integradora y un enfoque más centrado en el paciente en la atención sanitaria. Un enfoque multidisciplinario para el manejo de las afecciones musculoesqueléticas tiene el potencial para aliviar la presión del sistema de salud pública de emergencia. La colaboración interprofesional en el cuidado de la salud es primordial para que este sinergismo ocurra. Es crucial que las opciones de tratamiento sean coherentes y transparentes en las diferentes profesiones de la salud con el fin de que la atención centrada en el paciente sea óptima. Utilizando el marco educativo y de salud australiano como ejemplo, se argumenta en este trabajo que la educación en anatomía podría desempeñar un papel importante para facilitar esta consistencia y transparencia. El primer paso decisivo en este proceso sería revisar la alineación de los programas de anatomía a través de los programas académicos de diferentes profesiones de la salud. La revisión y comparación del contenido de la anatomía enseñada en los diferentes currículos de profesionales de la salud debería acelerar la aceptación de una profesión por otra. Esta alineación de la enseñanza de la anatomía ayudaría a las relaciones interprofesionales y, en última instancia, la colaboración, desde la educación de los estudiantes hasta la práctica profesional y las directrices de acreditación.

PALABRAS CLAVE: Educación en Anatomía; Condiciones musculoesqueléticas; Colaboración interprofesional; Atención médica multidisciplinaria.

\section{REFERENCES}

Bainbridge, L. Interprofessional education in allied health: is this yet another silo? Med. Educ., 48(3):229-31, 2014.

Barrow, M. Conflict in context: designing authentic teamwork education. Med. Educ., 46(10):926-7, 2012.

Brosnan, C. 'Quackery' in the academy? Professional knowledge, autonomy and the debate over complementary medicine degrees. Sociology, 1-18, 2015. DOI: 10.1177/ 0038038514557912

Chan, L. K. \& Pawlina, W. Teaching Anatomy: A Practical Guide. London, Springer, 2015.

Coulter, I. D. \& Willis, E. M. The rise and rise of complementary and alternative medicine: a sociological perspective. Med. $J$. Aust., 180(11):587-9, 2004.

Delgado, R.; York, A.; Lee, C.; Crawford, C.; Buckenmaier, C. 3rd.; Schoomaker, E.; Crawford, P. \& Active Self-Care Therapies for Pain (PACT) Working Group. Assessing the quality, efficacy, and effectiveness of the current evidence base of active self-care complementary and integrative medicine therapies for the management of chronic pain: a rapid evidence assessment of the literature. Pain Med., 15 Suppl. 1:S9-20, 2014.

Di Dio, L. J. The importance of anatomy. Ann. Anat., 181(5):455$65,1999$.

Elizondo-Omaña, R. E. \& López, S. G. The development of clinical reasoning skills: a major objective of the anatomy course. Anat. Sci. Educ., 1(6):267-8, 2008.

Farey, J. E.; Sandeford, J. C. \& Evans-McKendry, G. D. Medical students call for national standards in anatomical education. A. N. Z. J. Surg., 84(11):813-5, 2014.

Frenk, J.; Chen, L.; Bhutta, Z. A.; Cohen, J.; Crisp, N.; Evans, T.; Fineberg, H.; García, P. J.; Ke, Y.; Kelley, P.; Kistnasamy, B.; Meleis, A.; Naylor, D.; Pablos-Mendez, A.; Reddy, S.; Scrimshaw, S.; Sepulveda, J.; Serwadda, D. \& Zurayk, H. Health professionals for a new century: transforming education to strengthen health systems in an interdependent world. Rev. Peru. Med. Exp. Salud Publica., 28(2):337-41, 2011.

Harris, M. F.; Advocat, J., Crabtree, B. F., Levesque, J. F.; Miller, W. L.; Gunn, J. M.; Hogg, W.; Scott, C. M.; Chase, S. M.; 
Halma, L. \& Russell, G. M. Interprofessional teamwork innovations for primary health care practices and practitioners: evidence from a comparison of reform in three countries. $J$. Multidiscip. Healthc., 9:35-46, 2016.

Ho, K.; Jarvis-Selinger, S.; Borduas, F.; Frank, B.; Hall, P.; Handfield-Jones, R.; Hardwick, D. F.; Lockyer, J.; Sinclair, D.; Lauscher, H. N.; Ferdinands, L.; MacLeod, A.; Robitaille, M. A. \& Rouleau, M. Making interprofessional education work: the strategic roles of the academy. Acad. Med., 83(10):93440, 2008.

Hoy, D.; March, L.; Brooks, P.; Blyth, F.; Woolf, A.; Bain, C.; Williams, G.; Smith, E.; Vos, T.; Barendregt, J.; Murray, C.; Burstein, R. \& Buchbinder, R. The global burden of low back pain: estimates from the Global Burden of Disease 2010 study. Ann. Rheum. Dis., 73(6):968-74, 2014a.

Hoy, D. G.; Smith, E.; Cross, M.; Sanchez-Riera, L.; Blyth, F. M.; Buchbinder, R.; Woolf, A. D.; Driscoll, T.; Brooks, P. \& March, L. M. Reflecting on the global burden of musculoskeletal conditions: lessons learnt from the global burden of disease 2010 study and the next steps forward. Ann. Rheum. Dis., 74(1):4-7, 2014b.

Lombardi, M. M. Authentic learning for the 21st century: An overview. Educause Learning Initiative, ELI Paper 1, 2007.

McBride, J. M. \& Drake, R. L. Student perceptions of an interprofessional educational experience: The importance of goal articulation. Anat. Sci. Educ., 8(4):381-5, 2015.

McKinlay, E. \& Pullon, S. Having interprofessional education during the undergraduate years is essential for building teamwork skills in general practice: yes. J. Prim. Health Care, 6(4):331-3, 2014.

Moxham, B. J.; Plaisant, O.; Smith, C. F.; Pawlina, W. \& McHanwell, S. An approach toward the development of core syllabuses for the anatomical sciences. Anat. Sci. Educ., 7(4):302-11, 2014.

Murray, C. J.; Vos, T.; Lozano, R.; Naghavi, M.; Flaxman, A. D.; Michaud, C.; Ezzati, M.; Shibuya, K.; Salomon, J. A. \& Abdalla, S. Disability-adjusted life years (DALYs) for 291 diseases and injuries in 21 regions, 1990-2010: a systematic analysis for the Global Burden of Disease Study 2010. Lancet, 380(9859):2197-223, 2013.

O'Sullivan, P. It's time for change with the management of nonspecific chronic low back pain. Brit. J. Sports Med., 46(4):2247, 2012.

Pawlina, W. \& Drake, R. L. Authentic learning in anatomy: A primer on pragmatism. Anat. Sci. Educ., 9(1):5-7, 2016.

Pecukonis, E.; Doyle, O. \& Bliss, D. L. Reducing barriers to interprofessional training: promoting interprofessional cultural competence. J. Interprof. Care, 22(4):417-28, 2008.
Skinner, E. H.; Kimberley, J. H.; Hayes, K.; Seller, D.; Toohey, J. C.; Reeve, J. C.; Holdsworth, C. \& Haines, T. P. Future of specialised roles in allied health practice: who is responsible? Aust. Health Rev., 39(3):255-9, 2015.

Steketee, C.; Forman, D.; Dunston, R.; Yassine, T.; Matthews, L. R.; Saunders, R.; Nicol, P. \& Alliex, S. Interprofessional health education in Australia: three research projects informing curriculum renewal and development. Appl. Nurs. Res., 27(2):115-20, 2014.

Thistlethwaite, J. E.; Forman, D.; Matthews, L. R.; Rogers, G. D.; Steketee, C. \& Yassine, T. Competencies and frameworks in interprofessional education: a comparative analysis. Acad. Med., 89(6):869-75, 2014.

Thistlethwaite, J. E. Interprofessional education and the basic sciences: Rationale and outcomes. Anat. Sci. Educ., 8(4):299304, 2015.

Turney, B. W. Anatomy in a modern medical curriculum. Ann. R. Coll. Surgeons Engl., 89(2):104-7, 2007.

Yammine, K. Evidence-based anatomy. Clin. Anat., 27(6):847-52, 2014.

Correspondence to:

Rosemary Giuriato

Department of Chiropractic

Macquarie University

Sydney

NSW 2109

Australia

E-mail: rosemary.giuriato@mq.edu.au

Received: 02-08-2016

Accepted: 17-10-2016 